\title{
Urokinase in rheumatoid arthritis: causal or coincidental?
}

The past 10 years have witnessed an increased interest in the plasminogen activation system and its potential role(s) in rheumatoid arthritis (RA). Two types of plasminogen activators (PAs), urokinase (uPA) and tissue type PA (tPA), which are structurally, immunologically, and genetically distinct, have been identified in mammals. Both PAs are secreted as a single chain protein, which in the case of uPA is essentially inactive (pro-uPA). Pro-uPA is then converted by a single enzymatic cleavage into two chain active enzyme. uPA and tPA are highly specific serine proteases catalysing the conversion of plasminogen into plasmin. ${ }^{12}$ Plasminogen, present in plasma and extracellular fluids, can bind to fibrin and also to cell surface plasminogen receptors (PlnR), via its lysine binding sites. The activity of PAs is controlled by natural inhibitors (PAls), which include PAI-1, the main PAI in the circulation, and PAI-2. In addition, uPA activity is blocked by protease nexin 1 (PN-1). Another important step in the regulation of PA activity involves binding of tPA to fibrin, leading to increased catalytic activity of the enzyme, and binding of pro-uPA and uPA through a growth factor domain contained in their amino terminal region, to a specific, high affinity cell surface receptor, UPAR. Binding of uPA to UPAR increases the rate of plasminogen activation and greatly increases extracellular matrix degradation and cell invasion in vitro and in vivo. In addition, upon binding to uPAR, uPA shows effects that are independent of its proteolytic activity.

Non-inflammatory synovial membranes from normal subjects or osteoarthritis patients expressed predominantly tPA, at the activity and antigenic level, which was associated to blood vessels. ${ }^{34}$ In contrast, in RA synovial tissues, tPA expression was reduced, while uPA activity was increased. Its corresponding antigen and mRNA were also increased, and mainly associated to the synovial lining layer. $^{3-5}$ Increased levels of uPAR, PAI-1, and PAI-2 were also found in RA tissues. ${ }^{34}$ These results from synovial biopsy specimens were in agreement with previous studies on RA synovial fluids, where antigenic levels of uPA, PAI-1, and UPAR were increased compared with corresponding plasma values or with normal knee synovial fluid, while tPA levels were either decreased or unchanged..$^{6-9}$ Finally, increased uPA and decreased tPA antigenic levels measured in RA synovial fluids have been associated with the clinical severity of the disease. ${ }^{10}$ What is the cellular origin of uPA in the RA joint? In vitro studies showed that most of the cells present in the inflamed joint, mononuclear cells, polymorphonuclear cells, synovial fibroblasts, chondrocytes, and bone cells, express uPA together with variable amounts of uPAR and PAls when cultured in vitro (see fig 1). uPA expression can be up modulated by numerous growth factors and cytokines, such as interleukin $1 \beta$ and tumour necrosis factor $\alpha .{ }^{112} \mathrm{By}$ contrast, tPA, mainly produced by endothelial cells, is down modulated by the same cytokines. Thus, increased uPA levels and decreased tPA expression found in RA synovial tissues and fluids are probably accounted for by the opposing effects of cytokines on the two PAs genes.

Effects of uPA overexpression in RA joints can be mediated through both plasmin independent and plasmin dependent pathways (see fig 1). Secreted pro-uPA, upon binding to uPAR, could induce plasmin independent effects such as mitogenic, migratory, and adhesiveness responses, ${ }^{13}{ }^{14}$ which are potentially relevant to some of the

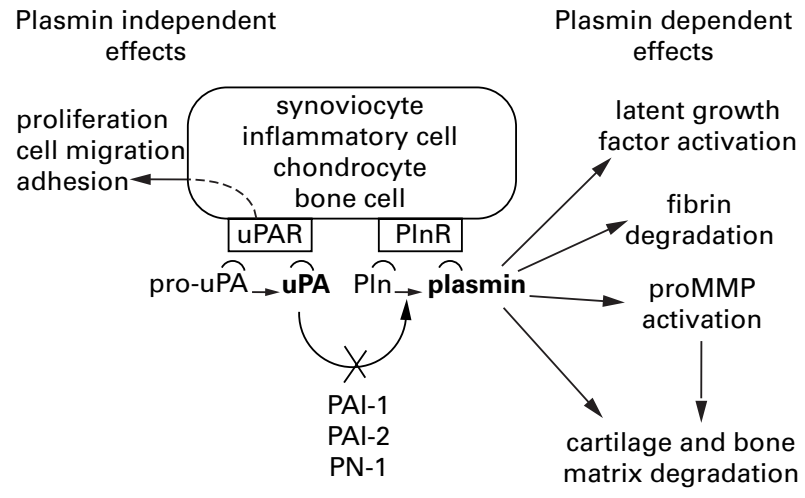

Figure 1 Schematic representation of the UPA mediated plasminogen activation within the $R A$ joint. Secreted pro-uPA, as well as active uPA, bind, through the aminoterminal non-catalytic portion, in an autocrine or paracrine way, to uPAR bearing cells. Upon uPAR occupancy, signal transduction may occur, leading to different plasmin independent effects. Alternatively, uPA converts plasminogen into plasmin, which has various different substrates. Plasminogen and plasmin bind to cell surface receptors, through lysine binding sites located in their non-catalytic domain. Active enzymes are indicated by bold style. $R=$ receptor, $P l n=$ plasminogen, $M M P=$ matrix metalloprotease, $P N-1=$ protease nexin $1, P A I=$ plasminogen activator inhibitor.

observed anomalies in RA synovium. Alternatively, active uPA can generate plasmin, a protease of broad specificity, which can act on numerous substrates within the joint. Plasmin has been shown to activate and mobilise latent forms of growth/angiogenic factors such as transforming growth factor $\beta$ and scatter factor; both factors are expressed within arthritic joints and believed to have important pathogenic effects. Modulation of uPA mediated proteolytic activity may therefore influence indirectly the growth and differentiation of cellular constituents in arthritic joints, although this role remains to be shown both in vitro and in vivo.

The best reported and probably also the most important substrates of plasmin are extracellular matrix proteins. uPA mediated plasminogen activation seems thus to be involved in two prominent features of RA characterised by extracellular matrix degradation: joint destruction and intra-articular fibrin turnover. Joint damage with cartilage and bone destruction is believed to be mediated mainly through the release of neutral proteases (represented by metalloproteases (MMPs) and plasmin) by activated synovial cells of the pannus, chondrocytes, and inflammatory cells. ${ }^{15}$ Plasmin may play a pivotal part in this degradative process as it can directly degrade cartilage proteoglycans as well as other cartilage and bone matrix proteins or indirectly, through the activation of latent MMPs. A contribution of uPA to cartilage and bone destruction has been shown in different in vitro experimental models. Degradation of cartilage explants induced by interleukin 1 or tumour necrosis factor $\alpha$ has been correlated with the induction of uPA activity. ${ }^{1617}$ Degradation of a radiolabelled bone-like matrix was achieved by mouse cells transfected with human uPA, but not by cells transfected with human $\mathrm{uPAR}^{18}$; moreover, cocultivation of UPA and UPAR expressing cells resulted in a pronounced increase in matrix degradation.

As an alternative view of the role of uPA in RA, we must consider its role in fibrin degradation. Accumulation of intra-articular fibrin is a common feature of RA, occurring on the synovial membrane, on the cartilage surface, and as 
particulate aggregates (the typical 'rice bodies') in synovial fluid. ${ }^{51920}$ These fibrin deposits are the results of the intra-articular balance between coagulation and fibrinolysis. Increased expression of tissue factor and factor XIIl by articular endothelial cells and macrophages have been reported, thus providing the ability to generate and cross link fibrin in RA synovial tissues. ${ }^{5}$ Degradation of fibrin matrix is performed by plasmin. ${ }^{21}$ The most tangible evidence of ongoing fibrinolysis is the generation of fibrin degradation products such as cross linked, plasmin modified fibrin (fibrin D-dimer). The presence of fibrin D-dimer was confirmed, using specific antibodies, in RA synovium. ${ }^{519}$ Although the role of uPA in intra-articular fibrin removal has not been assessed in vivo, the concomitant presence of fibrin D-dimer and increased uPA activity in RA synovial tissues, suggests ongoing uPA mediated fibrinolysis in RA joints. Interestingly, in other inflammatory situations, such as septic shock ${ }^{22}$ and lung injury, ${ }^{23}$ a correlation between extravascular fibrin deposition and decreased uPA activity has been found, supporting uPA as a crucial enzyme in extravascular fibrin clearance.

Intra-articular fibrin deposits can have potential adverse effects. The presence of fibrin on synovium and cartilage may impede normal nutrition to these tissues, thus amplifying conditions that lead to hypoxia and acidosis in synovial fluid, as suggested by Harris. ${ }^{20}$ Fibrin(ogen) degradation products may also have direct proinflammatory effects by increasing vascular permeability and inducing chemotaxis at sites of inflammation. ${ }^{24}{ }^{25}$ Finally, the extravascular fibrin meshwork serves as a provisional matrix for inflammatory cell adhesion. ${ }^{26}$ This potential arthrogenic role of fibrin in RA is supported by studies in animals where homologous fibrin injected intra-articularly in previously immunised rabbits induced a chronic inflammatory arthritis. ${ }^{27}$ The proinflammatory role of fibrin(ogen) in human joints has also been reported: a proportion of patients treated with silicon rubber joint prostheses developed synovial and osseous inflammation, ${ }^{28}$ probably mediated by the spontaneous adsorption of fibrinogen on the implanted polymer surfaces. ${ }^{29}$

uPA mediated proteolytic activity in RA has already been considered as a target for therapeutic intervention in this disease. It has been hypothesised that compounds inhibiting uPA mediated activity could represent new pharmacological tools to reduce joint destruction. Indeed, clinical improvement of arthritic patients was seen after intraarticular injection of urinary trypsin inhibitor, which was shown to inhibit uPA. ${ }^{30}$ In this context, the finding that glucocorticosteroids suppress uPA activity of human synovial cells, chondrocytes, and mononuclear cells ${ }^{11}$ could represent one of the mechanisms leading to the beneficial effects of these anti-inflammatory drugs in the treatment of RA. On the other hand, as discussed above, intra-articular fibrin may be highly detrimental in RA. Thus, agents able to decrease extravascular fibrin deposition might ameliorate RA synovitis. Belch et $a l^{\beta 1}$ noted that the anabolic androgenic steroid stanozolol increased plasma fibrinolytic activity and improved inflammation in RA patients. It was postulated that the improvement may be attributable to a reduction in synovial fibrin, mediated by the increased fibrinolytic activity.

Variations in uPA activity levels could occur during the course of the disease and within the joint, favouring one or another feature of RA. The relative importance of the contrasting roles of uPA in RA pathogenesis (deleterious with respect to joint destruction, beneficial in the context of fibrin mediated inflammation) needs to be assessed in vivo. The availability of animals genetically deficient in $\mathrm{uPA}^{32}$ offers us the means to clarify the uPA role(s) in arthritis. Ultimately, elucidation of the in vivo role of uPA in arthri- tis pathogenesis could lead to the elaboration of new therapeutic strategies for RA.

NATHALIE BUSSO

ALEXANDER SO

Centre Hospitalier Universitaire Vaudois, Laboratoire de Rhumatologie, Beaumont 02-224,1011 Lausanne, Switzerland

Correspondence to:

Dr N Busso.

1 Dano K, Andreasen PA, Grondahl-Hansen J, Kristensen P. Nielsen LS, Skriver L. Plasminogen activators, tissue degradation, and cancer. Adv Cancer Res 1985;44:139-266.

2 Vassalli JD, Sappino AP, Belin D. The plasminogen activator/plasmin system. J Clin Invest 1991;88:1067-72.

3 Ronday HK, Smits HH, van Muijen GN, Pruszcynski MS, Dolhain RJ, van Langelaan EJ, et al. Difference in expression of the plasminogen activation system in synovial tissue of patients with rheumatoid arthritis and osteoarsystem in synovial tissue of patients with
thritis. Br J Rheumatol 1996;35:416-23.

4 Busso N, Peclat V, So A, Sappino AP. Plasminogen activation in synovial tissues: differences between normal, osteoarthritis, and rheumatoid arthritis joints. Ann Rheum Dis 1997;56:550-7.

5 Weinberg JB, Pippen AM, Greenberg CS. Extravascular fibrin formation and dissolution in synovial tissue of patients with osteoarthritis and rheumatoid arthritis. Arthritis Rheum 1991;34:996-1005.

6 Brommer EJ, Dooijewaard G, Dijkmans BA, Breedveld FC. Depression of tissue-type plasminogen activator and enhancement of urokinase-type plasminogen activator as an expression of local inflammation. Thromb Haemost 1992;68:180-4.

7 Kummer JA, Abbink JJ, de Boer JP, Roem D, Nieuwenhuys EJ, Kamp AM, et al. Analysis of intraarticular fibrinolytic pathways in patients with inflammaal. Analysis of intraarticular fibrinolytic pathways in patients with inflamma-

8 Saxne T, Lecander I, Geborek P. Plasminogen activators and plasminogen activator inhibitors in synovial fluid. Difference between inflammatory joint disorders and osteoarthritis. J Rheumatol 1993;20:91-6.

9 Belcher C, Fawthrop F, Bunning R, Doherty M. Plasminogen activators and their inhibitors in synovial fluid from normal, osteoarthritis, and rheumatoid arthritis knees. Ann Rheum Dis 1996;55:230-6.

10 Brommer EJ, Dooijewaard G, Dijkmans BA, Breedveld FC. Plasminogen activators in synovial fluid and plasma from patients with arthritis. Ann Rheum Dis 1992;51:965-8.

11 Hamilton JA, Campbell IK, Wojta J, Cheung D. Plasminogen activators and their inhibitors in arthritic disease. Ann NY Acad Sci 1992;667:87-100.

12 Allan EH, Martin TJ. The plasminogen activator inhibitor system in bone cell function. Clin Orthop 1995;313:54-63.

13 Rabbani SA, Mazar AP, Bernier SM, Haq M, Bolivar I, Henkin J, et al. Structural requirements for the growth factor activity of the aminoterminal domain of urokinase activity. FEBS Lett 1992;267:14151-6.

14 Waltz DA, Chapman HA. Reversible cellular adhesion to vitronectin linked to urokinase receptor occupancy. J Biol Chem 1994;269:14746-50.

15 Werb Z, Alexander CM. Proteinases and matrix degradation. In: Kelley WN, Harris ED, Ruddy S, Sledge CB, eds. Textbook of rheumatology. 4th ed. Philadelphia: W B Saunders, 1993:248-68.

16 Collier S, Ghosh P. The role of plasminogen in interleukin-1 mediated cartilage degradation. J Rheumatol 1988;15:1129-37.

17 Campbell IK, Piccoli DS, Roberts MJ, Muirden KD, Hamilton JA. Effects of tumor necrosis factor alpha and beta on resorption of human articular cartilage and production of plasminogen activator by human articular chondrocytes. Arthritis Rheum 1990;33:542-52.

18 Ronday HK, Smits HH, Quax PHA, Van Der Pluijm G, Lowik CWGM, Breedveld FC, et al. Bone matrix degradation by the plasminogen activation system. Possible mechanism of bone destruction in arthritis. Br J Rheumatol 1997;36:9-15.

19 Zacharski LR, Brown FE, Memoli VA, Kisiel W, Kudryk BJ, Rousseau SM, et al. Pathways of coagulation activation in situ in rheumatoid synovial tissue. Clin Immunol Immunopathol 1992;63:155-62.

20 Harris ED. Etiology and pathogenesis of rheumatoid arthritis. In: Kelley WN, Harris ED, Ruddy S, Sledge CB, eds. Textbook of rheumatology. 4th ed. Philidelphia: W B Saunders, 1993:833-873

21 Collen D, Lijnen HR. Fibrin-specific fibrinolysis. Ann N Y Acad Sci 1992; 667:259-71.

22 Yamamoto K, Loskutoff DJ. Fibrin deposition in tissues from endotoxintreated mice correlates with decreases in the expression of urokinase-type but not tissue-type plasminogen activator. J Clin Invest 1996;97:2440-51.

23 Olman MA, Mackman N. Gladson CL, Moser KM, Loskutoff DJ. Changes in procoagulant and fibrinolytic gene expression during bleomycin-induced lung injury in the mouse. J Clin Invest 1995;96:1621-30.

24 Dvorak HN, Senger DR, Dvorak AM, Harvey VS, McDonagh J. Regulation of extravascular coagulation by microvascular permeability. Science 1985;227:1059-61

25 Senior RM, Skogen WF, Griffin GL, Wilner GD. Effects of fibrinogen derivatives upon the inflammatory response. Studies with human fibrinopeptide B. J Clin Invest 1986;77:1014-9.

26 Altieri DC. Coagulation assembly on leukocytes in transmembrane signaling and cell adhesion. Blood 1993;81:569-79.

27 Dumonde DC, Glynn LE. The production of arthritis in rabbits by an immunological reaction to fibrin. Br J Exp Pathol 1962;43:373-83.

28 Gordon M, Bullough PG. Synovial and osseous inflammation in failed silicone-rubber prostheses. J Bone Joint Surg 1982;64:574-80.

29 Tang L, Eaton JW. Fibrin(ogen) mediates acute inflammatory responses to biomaterials. J Exp Med 1993;178:2147-56.

30 Kikuchi H. Tanaka S. Matsuo O. Plasminogen activator in synovial fluid from patients with rheumatoid arthritis. J Rheumatol 1987;14:439-45.

31 Belch JJ, Madhok R, McArdle B, McLaughlin K, Kluft C, Forbes CD, et al. The effect of increasing fibrinolysis in patients with rheumatoid arthritis: a double blind study of stanozolol. Q J Med 1986;58:19-27.

32 Carmeliet P, Schoonjans L, Kieckens L, Ream B, Degen J, Bronson R, et al. Physiological consequences of loss of plasminogen activator gene function in mice. Nature 1994;368:419-24. 